Jurnal Sistem Informasi (Journal of Information Systems). 1/13 (2017), 11-20

DOI: http://dx.doi.org/10.21609/jsi.v13i1.514

\title{
ANALISIS PENGUKURAN TINGKAT KESIAPAN PENERAPAN MANAJEMEN PENGETAHUAN: STUDI KASUS BADAN PENDIDIKAN DAN PELATIHAN KEUANGAN, KEMENTERIAN KEUANGAN
}

\author{
Hafid Mukhlasin, Indra Budi \\ Magister Teknologi Informasi, Fakultas Ilmu Komputer, Universitas Indonesia, Jalan Salemba Raya \\ Nomor 4, Jakarta, 10430, Indonesia \\ E-mail: hafidmukhlasin@gmail.com, indra@cs.ui.ac.id
}

\begin{abstract}
One strategy of the Ministry of Finance in the institutional transformation is to strengthen the role of Financial Education and Training Agency (FETA) in the development of human resources is to become a corporate university. Furthermore, base on theory that one of the important elements that should exist in an organization to become a corporate university is knowledge management (KM). The problem which occurs in FETA is that the organization does not have specific mechanisms to manage the knowledge. Moreover, to overcome that problem, the organization need to build a KM system that allows each individual to share useful knowledge for the organization. As the first step, it needs a good preparation to lessen the failure in implementing it; which is by measuring the readiness level of knowledge management implementation. Therefore, this study aims to measure the readiness level of knowledge management implementation in FETA in order to provide recommendations for improving the readiness of it. The readiness level is measured based on the variables mapping including KM Infrastructure, KM Enabler, and KM Critical Success Factor and then mapped into the KM aspects. The data were collected by using a sample survey method which were gathered from the employees of FETA. The data are then analyzed descriptively and inferentially to get the description about the readiness level of FETA in implementing knowledge management. Based on this research, it can be concluded that FETA is at the receptive level of readiness in implementing knowledge management. It indicates that all the indicators in KM, have been very supportive to the implementation of KM in FETA.
\end{abstract}

Keywords: knowledge management, knowledge management readiness, KM enabler, KMCSF, KM infrastructure

\begin{abstract}
Abstrak
Salah satu strategi Kementerian Keuangan dalam transformasi kelembagaan adalah memperkuat pe-ran Badan Pendidikan dan Pelatihan Keuangan (BPPK) dalam pengembangan sumber daya manusia yaitu dengan menjadi corporate university. Berdasarkan teori, salah satu elemen penting yang harus ada pada sebuah organisasi untuk menjadi corporate university adalah manajemen pengetahuan (KM). Permasalahan yang terjadi adalah BPPK belum memiliki mekanisme untuk mengelola pengetahuan tersebut. Untuk mengatasi hal tersebut, BPPK perlu membangun sistem KM sehingga memudahkan setiap individu untuk berbagi pengetahuan yang bermanfaat bagi organisasi. Sebagai langkah awal, diperlukan persiapan yang matang untuk mengurangi kegagalan dalam penerapannya yaitu dengan mengukur tingkat kesiapan penerapan KM. Oleh karenanya penelitian ini bertujuan mengukur tingkat kesiapan penerapan KM di BPPK sehingga dapat memberikan rekomendasi untuk meningkatkan kesiapannya. Tingkat kesiapan ini diukur berdasarkan pemetaan variabel KM Infrastructure, KM Enabler, dan KM Critical Success Factor yang kemudian dipetakan ke dalam aspek KM. Data penelitian dikumpulkan menggunakan metode survei tehadap sampel pegawai BPPK. Data tersebut kemudian dianalisis secara deskriptif dan inferensial untuk mendapatkan gambaran tentang tingkat kesiapan BPPK. Berdasarkan penelitian ini diketahui bahwa BPPK berada pada tingkat receptive yang mengindikasikan bahwa semua indikator dalam KM sudah sangat mendukung untuk diterapkannya KM di BPPK
\end{abstract}

Kata Kunci: manajemen pengetahuan, kesiapan manajemen pengetahuan, KM enabler, KMCSF, KM infrastructure

\section{Pendahuluan}

Berdasarkan Peraturan Menteri Keuangan (PMK) nomor 184 tahun 2010 tentang organisasi dan tata kerja kementerian keuangan (Kemenkeu) [1], bah- wa Kemenkeu memiliki unit eselon satu yang memiliki tugas utama melaksanakan pendidikan dan pelatihan (diklat) di bidang keuangan negara yaitu Badan Pendidikan dan Pelatihan Keuangan (BPPK). 
Untuk mendukung reformasi birokrasi sebagaimana yang diamanatkan oleh pemerintah melalui peraturan presiden (Perpres) nomor 81 tahun 2010 tentang grand design RB 2010-2015 [2], maka Kemenkeu melakukan transformasi kelembagaan yang diatur dalam keputusan menteri keuangan (KMK) nomor 36 tahun 2014 tentang cetak biru program transformasi kelembagaan Kemenkeu tahun 2014-2025 [3].

Berdasarkan KMK nomor 36 tahun 2014 tersebut, bahwa terdapat peluang untuk memperkuat peran BPPK sebagai badan diklat agar dapat memainkan peran yang lebih besar dalam transformasi Kemenkeu yaitu dengan menjadikan BPPK sebagai unit yang memiliki peran strategis dalam pengembangan sumber daya manusia (SDM) di Kemenkeu.

Allen [4] mendefinisikan bahwa corporate university (Corpu) adalah entitas pendidikan yang merupakan alat strategis yang dirancang untuk membantu organisasi. Di samping itu, Allen [5] juga menjelaskan bahwa Corpu adalah penanggung jawab dalam pengembangan SDM dan peningkatan kemampuan organisasi.

Berdasarkan konsep tersebut dapat disimpulkan bahwa transformasi BPPK merupakan sebuah perubahan bentuk organisasi dari unit diklat biasa menjadi sebuah Corpu.

Berkaitan dengan hal tersebut, melalui keputusan menteri keuangan nomor 466 tahun 2015 tentang rencana strategis (renstra) Kemenkeu 2015-2019 [6], bahwa salah satu strategi yang dilakukan adalah melakukan integrasi diklat yang jelas dan menyeluruh dengan konsep Corpu melalui penguatan lembaga pendidikan kedinasan yang saat ini ada dan penguatan fungsi perencanaan, pengembangan dan evaluasi pelatihan untuk menjamin terjadinya link and match dengan tujuan strategis dari organisasi.

Menurut Alen [5], salah satu elemen penting yang harus ada dalam sebuah organisasi untuk menerapkan konsep Corpu adalah adanya manajemen pengetahuan (KM). Hal ini juga senada dengan Perpres nomor 81 tahun 2010 [2] bahwa strategi RB adalah menerapkan KM agar terjadi suatu proses pembelajaran dan tukar pengalaman yang efektif bagi organisasi dalam melaksanakan reformasi birokrasi.

Apabila ditinjau dari sudut pandang SDM, maka dapat diketahui fakta bahwa tingkat mutasi dan promosi pegawai BPPK pada dua tahun terakhir (2014 dan 2015) mencapai lebih dari sepertiga (35\%) jumlah pegawai BPPK yang aktif. Padahal menurut Mulyono, Harisno, dan Kristianto [7], pengetahuan yang ada pada individu ini bisa saja hilang ketika mereka tidak lagi berada pada jabatan tersebut dalam organisasi hal ini karena pengetahuan yang tersimpan di dalam individu akan ikut berpindah bersama dengan pemiliknya apabila tidak terdokumentasi dengan baik.

Oleh karena itu perlu adanya mekanisme untuk mengelola pengetahuan dengan baik sehingga memudahkan setiap individu untuk berbagi pengetahuan maupun belajar hal baru yang bermanfaat bagi organisasi. Berdasarkan hasil wawancara dengan pejabat internal diperoleh informasi BPPK memang belum menerapkan KM.

KM ini sejalan dengan salah satu strategi BPPK yang tertuang dalam rencana strategis (Renstra) BPPK 2015-2019 [6], terutama untuk mendukung arah kebijakan dan strategi BPPK terkait pengembangan SDM yaitu pengembangan KM untuk kebutuhan diklat yang diarahkan untuk menjadi bagian utama dalam pengembangan sistem KM Kemenkeu.

Sebelum menerapkan KM pada organisasi, perlu dilakukan pengukuran kesiapannya sehingga diharapkan bisa mengurangi risiko kegagalan dalam penerapan manajemen pengetahuan tersebut. Menurut Atrinawati dan Surendro [8], beberapa proyek penerapan KM mengalami kegagalan. Hal itu terjadi karena penerapan hanya dilakukan berdasarkan teori dan tidak mempertimbangkan aspek-aspek tertentu dari organisasi.

Berdasarkan hasil wawancara yang dilakukan, dapat disimpulkan bahwa BPPK hingga saat ini belum melakukan kajian yang mengukur kesiapan penerapan KM. Oleh karena itu pertanyaan penelitian ini adalah sejauh mana tingkat kesiapan BPPK dalam menerapkan manajemen pengetahuan.

Tujuan yang ingin dicapai dari penelitian ini yaitu: mengetahui tingkat kesiapan BPPK dalam menerapkan KM sehingga dapat memberikan rekomendasi berupa strategi perbaikan untuk meningkatkan kesiapan BPPK dalam menerapkan KM tersebut.

\section{Perkembangan Rencana Penerapan KM BPPK}

Berdasarkan hasil observasi dan wawan-cara terkait kondisi perkembangan BPPK menuju penerapan KM, maka dapat disimpulkan bahwa:

1) Ada arahan dan komitmen dari pimpi-nan tertinggi dalam hal ini Menteri Keuangan dan Kepala BPPK untuk membangun KM yang disampaikan pada kegiatan resmi BPPK (Rakor BPPK 2016)

2) BPPK telah membentuk tim KM pusat yg bertugas untuk melakukan insialisasi KM di BPPK seperti menyusun kebijakan atau peraturan terkait $\mathrm{KM}$, merancang prototype $\mathrm{KM}$, merancang KMS, mengadakan workshop KM

3) BPPK telah mempersiapkan prototype model KM dimana KM dibagi menjadi dua yaitu KLC (Knowledge Learning Center) sebagai media 
atau tempat belajar dan KBS (Knowledge Base System) sebagai tempat penyimpanan pengetahuan. Prototype ini akan dijalankan untuk BPPK dan Pusdiklat mulai tahun 2017, untuk kemudian jika dianggap bagus maka akan dijadikan model KM bagi unit eselon 1 lain di Kemenkeu sampai akhirnya menjadi model KM Kemenkeu.

4) BPPK telah menyelenggarakan work-shop KM sebanyak dua kali (Oktober 2016 dan November 2016) yang dihadiri oleh perwakilan dari tiap Pusdiklat. Tujuan dari workshop ini ada-lah memberikan pemahaman tentang KM sehing-ga setiap Pusdiklat dapat menerapkan KM yang sejalan dengan rencana strategis BPPK.

5) BPPK telah mengadakan workshop KM sebanyak tiga angkatan, yang materinya lebih ke arah teknis TI yaitu tentang pembuatan materimateri digital (multimedia) yang nantinya sebagai media penyebaran pengetahuan.

6) BPPK telah mengadakan studi banding ke organisasi atau perusahaan yang telah sukses menerapkan KM seperti Telkom dan Pertamina.

7) BPPK telah membentuk tim KM Pus-diklat yang bertugas memberikan kontribusi terhadap prototype aplikasi KLC berupa materi diklat dari Pusdiklat

8) Widyaiswara dan dosen BPPK akan menjadi ujung tombak KM BPPK, dalam hal: pengisi konten, tim sosialisasi, fasilitator pembuatan materi digital.

9) BPPK telah memiliki aplikasi-aplikasi lain yang cukup menunjang untuk proses KM seperti BPPK TV, forum intranet BPPK, SIM Diklat, SMS gateway, dsb.

10) Di samping itu, BPPK mulai tahun 2016 ini mencanangkan program internalisasi nilai-nilai Kemenkeu (INKK). Adapun nilai-nilai Kemenkeu tersebut yaitu: integritas, profesionalisme, sinergi, pelayanan dan kesempurnaan. Terdapat beberapa kegiatan dalam nota dinas tersebut yang terkait dengan KM, yaitu:

a) Penyebarluasan informasi mengenai kode etik dan disiplin pegawai secara rutin terutama untuk pegawai baru.

b) Melakukan knowledge sharing minimal satu minggu sekali untuk meningkatkan pengetahuan pegawai dalam melaksanakan tugas seharihari.

c) Akses ke surat elektronik yang berguna untuk menambah pengetahuan pegawai mengingat Kemenkeu senantiasa mengirimkan informasi terkait kegiatan, kebijakan, maupun buletin yang diterbitkan oleh Kemenkeu.

d) Melakukan sosialisasi tugas dan fungsi serta uraian jabatan kepada pegawai yang beralih tugas atau yang menduduki jabatan baru

e) Akses ke intranet, yang mana intranet sebagai wadah berbagi informasi dapat juga digu- nakan sebagai sarana untuk saling berinteraksi. Dengan mengakses intranet setiap hari, pegawai BPPK diharapkan mampu memperoleh informasi terkait BPPK.

\section{Manajemen Pengetahuan (KM)}

Menurut Fernandez dan Sabherwal [9], Crane [12], dan Cheng [11], KM dapat diartikan sebagai strategi manajemen dalam hal menemukan, menangkap, berbagi, dan menerapkan pengetahuan dengan tujuan untuk mendukung organisasi dalam menciptakan struktur yang mampu mempertahankan, menciptakan dan menerapkan pengetahuan yang tidak hanya untuk pemecahan masalah tetapi juga untuk mencapai tujuan orga-nisasi.

\section{KM Readiness}

$\mathrm{KM}$ readiness adalah seperangkat kemampuan suatu organisasi atau perusahaan untuk mencapai infrastruktur yang dibutuhkan dalam KM serta kapasitas dalam memanfaatkannya Holt, Bartczak, Clark, dan Trent [13]. Adapun menurut Karim, Mohammad, Abdullah, dan Razi [14], KM readiness adalah sikap anggota organisasi ter-hadap KM (pesimisme, afektif, kelangsungan, dan normatif) dan menemukan faktor-faktor yang memengaruhinya (individu, konteks, konten, dan proses).

Menurut Mohammadi, Khanlari, dan Sohrabi [15], KM readiness adalah kemampuan organisasi, departemen, atau suatu kelompok supaya da-pat berhasil mengadopsi dan mengambil manfaat dari KM. KM readiness dapat menjawab dua pertanyaan dasar, yaitu: 1) Bagaimana kondisi kemampuan KM organisasi saat ini? 2) Perubahan apa yang diperlukan organisasi sebelum mengimplementasikan KM?

\section{Solusi dan Pondasi KM}

Menurut Fernandez dan Sabherwal [9], KM bergantung pada dua aspek yaitu solusi KM dan pondasi KM. Solusi KM mengacu kepada langkahlangkah spesifik KM yaitu (menemukan, menangkap, berbagi, dan menerapkan pengetahuan) yang dapat dicapai.

Adapun pondasi KM mengacu pada aspek organisasi secara keseluruhan yang mendukung KM baik jangka pendek maupun jangka panjang. Solusi KM meliputi proses KM dan sistem KM sedangkan pondasi KM meliputi: infrastuktur KM, mekanisme KM, dan teknologi KM.

Sesuai dengan konteks organisasi, infrastruktur KM meliputi lima komponen utama (budaya organisasi, struktur organisasi, infrastruktur teknologi informasi, pengetahuan umum, dan lin- 
gkungan fisik), mekanisme KM adalah cara atau langkah-langkah yang digunakan organisasi atau struktural untuk mempromosikan KM, sedangkan teknologi $\mathrm{KM}$ adalah teknologi informasi yang dapat digunakan untuk memfasilitasi KM.

Terkait dengan pengukuran kesiapan KM, maka komponen-komponen yang perlu diukur adalah komponen-komponen pada area KM foundation. Hal ini karena komponen-komponen pada area inilah yang menjadi pondasi atau kaki dari berdirinya KM.

\section{KM Enabler}

Menurut Lee dan Choi [16], KM enabler sebagai mekanisme organisasi dalam mengembangkan KM secara konsisten. Fitriadi [17] telah mengidentifikasi KM enabler dari hasil penelitian sebelumnya, bahwa terdapat tiga KM enabler yaitu struktur organisasi, budaya organisasi dan infrastruktur TI.

Adapun Setiawan [18] juga telah mengidentifikasi KM enabler dari penelitian sebelumnya, bahwa terdapat sembilan KM enabler yaitu organisasi, budaya, pembelajaran, kepemimpinan, dukungan IT, T-shaped skill, strategi, proses, dan pengetahuan.

Komponen-komponen di atas jika dikaitkan dengan solusi dan pondasi KM maka masuk ke area KM foundation.

\section{KM Critical Success Factor}

KMCSF (KM Critical Success Factor) me-rupakan faktor-faktor yang menjadi kunci keber-hasilan penerapan KM pada suatu organisasi. Hal ini sebagaimana yang dipaparkan Al-Mabrouk [19], bahwa KMCSF telah diidentifikasi dan dia-kui sebagai dasar bagi keberhasilan organisasi dan peningkatan kinerja pada berbagai bidang kegia$\tan$.

Faktor-faktor KMCSF yang digunakan pada penelitian ini merujuk pada lima penelitian sebelumnya sebagai berikut.

1) Nejadhussein dan Azadbakht [20] yaitu: monopoli pengetahuan, pengetahuan adalah kekuatan, reward dan pengakuan, kepercayaan, sum-ber pengetahuan, kurangnya atmosfer kerjasama, kurangnya ketertarikan menggunakan teknologi informasi, kompetisi antar individu, kurangnya kerjasama profesional antara professor di universitas, skill riset yang minim, pendidikan yang melampaui batas, kurangnya relevansi program diklat terkait inisiatif KM, kurangnya dukungan untuk berpartisipasi dalam seminar dan konferensi, kurangnya tempat bagi para staf untuk bertemu satu sama lain, kurangnya kerjasama dengan sektor industri untuk melakukan riset.
2) Pradana dkk [21] yaitu: keahlian berbentuk $\mathrm{T}$, kepemimpinan, kemampuan dan keahlian yang dibutuhkan dalam tugas, motivasi, suasana keja unit, ekspektasi performa dan ekspektasi usaha, struktur informal, struktur desentralisasi.

3) Rafieyzadeh [22] yaitu: budaya organisasi, kepemimpinan organisasi, strategi organisasi, teknologi informasi, akuisisi pengetahuan, konversi pengetahuan, penyimpanan pengetahuan dan pemanfaatan pengetahuan.

4) Mamaghani dkk [23] yaitu: strategi pengetahuan, dukungan manajemen, pengukuran performa, struktur organisasi, pembelajaran organisasi, dukungan keuangan, budaya organisasi, dorongan motivasi, komunikasi dan kerja kelompok, infrastuktur teknis, operasional terpadu, keamanan.

5) Al-Bastaki dan Shajera [24] yaitu: kepercayaan, kolaborasi, pembelajaran, desentralisasi, informal, sistem reward, dukungan TI.

\section{Kerangka Kerja KM Readiness}

Kerangka kerja KM readiness yang digunakan untuk penilaian kesiapan organisasi dalam menerapkan KM ini dibuat memetakan variabel dari KM infrastructure, KM enabler, dan KMCS.

Hal ini karena, KM infrastructure merupakan bagian dari KM foundation yang dapat digunakan untuk mengetahui kesiapan KM. Adapun menurut Holt dkk [13], faktor KM enabler juga menunjukkan kesiapan suatu organisasi terhadap KM. Demikian juga menurut Mohammadi, Khanlari, dan Sohrabi [15], instrumen yang digunakan untuk melakukan penilaian dapat dibangun berdasarkan KMCSF.

Penilaian kesiapan organisasi terhadap penerapan KM dapat direalisasikan menggunakan survei dengan respondennya adalah manajer maupun staf (Mahmod, Rosnan, dan Hazman-Fitri [25]). Selain itu, kesiapan ini perlu diukur agar penerapan KM pada organisasi bisa berjalan lancar sesuai rencana. Hal ini sebagaimana yang disam-paikan oleh Fernandez dan Sabherwal [9], bahwa pengukuran KM merupakan faktor penting (critical factor) dalam penerapan KM.

\section{Aspek KM}

Menurut Hlupic, Pouloudi, dan Rzevski [26], aspek dari KM dapat dibagi menjadi tiga, yaitu: 1) hard, 2) soft, 3) abstract.

Aspek hard atau teknis merupakan peralatan yang diperlukan untuk menciptakan pengetahuan, mengodifikasi pengetahuan, dan memindahkan pengetahuan dari individu ke departemen serta ke organisasi. 
Aspek soft yaitu aspek KM yang dipengaruhi oleh manusia dan organisasi, sedangkan aspek $a b$ stract yaitu terkait dengan pemahaman individu terhadap definisi KM, manfaat dan peranan KM, serta dampak KM bagi organisasi dan bagaimana menerapkan KM.

Pada penelitian ini, variabel penelitian diklasifikasikan berdasarkan tiga aspek KM.

\section{Metode Penelitian}

\section{Alur Penelitian}

Rujukan yang digunakan untuk menyusun alur penelitian adalah berasal dari Creswell [27] dan Sugiyono [28] kemudian diolah kembali untuk disesuaikan dengan kondisi penelitian ini ditunjukkan oleh Gambar 1.

\section{Populasi dan Sampel}

Populasi yang dijadikan objek penelitian adalah semua pegawai BPPK (PNS) yaitu 1.316 orang yang tersebar di 13 wilayah Indonesia, dikurangi dengan pegawai yang dipekerjakan di luar instansi BPPK (20 pegawai), sehingga totalnya 1296.

Untuk menentukan ukuran atau jumlah sampel yang dibutuhkan dalam penelitian ini menggunakan metode Slovin yaitu metode yang umum dan mudah digunakan untuk menghitung jumlah sampel minimal. Adapun rumus $\mathrm{n}=\mathrm{N} /\left(1+\mathrm{Ne}^{2}\right)$. Diketahui jumlah populasi $(\mathrm{N})$ adalah 1.296, dan batas toleransi kesalahan $(\mathrm{e})=5 \%$ karena penelitian ini adalah penelitian sosial. Oleh karena itu, didapatkan bahwa jumlah sampel mini-mal yang dibutuhkan sebanyak 306 sampel.

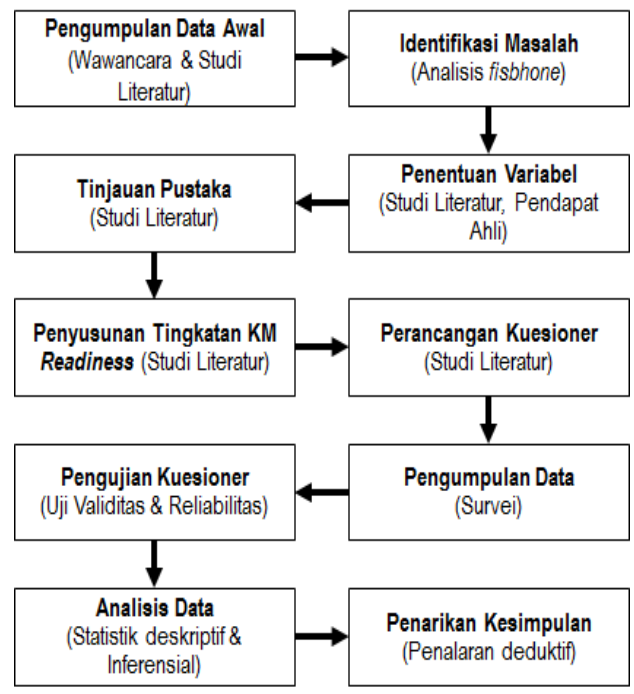

Gambar 1. Alur Penelitian

\section{Metode Pengumpulan Data}

Berdasarkan kedelapan penelitian terdahulu Nejadhussein dkk [20], Pradana dkk [21], Rafieyzadeh dkk [22], Mamaghani dkk [23], Al-Bastaki dan Shajera, [24], Zaidiah, [29], Fitriadi, [17], dan Setiawan, [18] yang telah dibahas pada bagian sebelumnya yang sama-sama menggunakan metode pengumpulan data survei dengan instrumennya adalah kuesioner, maka penelitian ini juga menggunakan metode tersebut.

Menurut Sugiyono [28] metode survei adalah metode penelitian yang dilakukan pada populasi besar maupun kecil, tetapi data yang dipela-jari adalah data dari sampel yang diambil dari po-pulasi tersebut.

\section{Metode Analisis Data}

Rumusan masalah pada penelitian ini ter-golong rumusan masalah deskriptif yaitu rumusan masalah yang berkenaan dengan pertanyaan terhadap keberadaan variabel mandiri baik hanya pada satu variabel atau lebih, tidak ada perbandingan antar variabel serta tidak ada pencarian hubungan antar variabel. Oleh karenanya menurut Sugiyono [28], analisis datanya menggunakan metode statistik deskriptif.

Pada penelitian ini, hipotesis tidak dirumuskan sehingga analisis data difokuskan untuk menjawab pertanyaan penelitian, namun apabila hipotesis dirumuskan maka analisis data difokuskan untuk menguji hipotesis (Sugiyono [28]).

Oleh karenanya untuk menjawab pertanyaan penelitian ini maka dilakukan dengan cara menghitung bobot rata-rata dari setiap jawaban atas item pertanyaan pada setiap variabel. Untuk ke-mudian hasil dari rata-rata setiap variabelnya dikelompokkan berdasarkan aspeknya baru kemudian dihitung rata-rata totalnya untuk dibandingkan dengan level kesiapan KM.

Hanya saja menurut Sugiyono [28], analis-is deskriptif tidak serta merta dapat digunakan untuk mengambil kesimpulan secara general pada populasi melainkan hanya berlaku untuk sampelnya saja. Oleh karena itu hasil perhitungan tersebut perlu diuji terlebih dahulu, hal ini dimaksudkan supaya bisa digeneralisir ke populasi. Adapun nilai hipotesis disusun berdasarkan persentase pada tingkatan kesiapan KM.

Misalnya jika nilai rata-rata total berada pada kesiapan KM tingkat ready (41\% sampai dengan $60 \%$ ) maka rumusan hipotesisnya yaitu hipotesis nol adalah nilai rata-rata total lebih besar sama dengan $41 \%$, sedangkan hipotesis alternatif: nilai rata-rata total kurang dari $41 \%$. Atau bisa disingkat menjadi $\mathrm{H}_{0}: \mu_{0} \geq 41 \%$ dan $\mathrm{H}_{\mathrm{a}}: \mu_{0}<41 \%$. 
TABEL 1

VARIABEL DAN INDIKATOR PENELITIAN

\begin{tabular}{|c|c|c|}
\hline No & Variabel & Indikator \\
\hline \multirow[t]{3}{*}{1} & \multirow{3}{*}{$\begin{array}{l}\text { Budaya } \\
\text { organisasi }\end{array}$} & Adanya rasa saling percaya antar individu untuk berbagi pengetahuan [20], [24] \\
\hline & & Adanya komunikasi yang terjalin antar individu dalam rangka berbagi pengetahuan [23] \\
\hline & & Adanya kolaborasi atau kerjasama antar individu dalam rangka berbagi pengetahuan $[20],[24],[21],[18]$ \\
\hline \multirow[t]{4}{*}{2} & \multirow{4}{*}{$\begin{array}{l}\text { Struktur } \\
\text { organisasi }\end{array}$} & Adanya unit / SDM (Chief Knowledge Officer) untuk mendukung KM [9] \\
\hline & & $\begin{array}{l}\text { Adanya fleksibilitas aturan dan prosedur yang ada di organisasi sehingga mendorong proses KM / } \\
\text { informalisasi [21] }\end{array}$ \\
\hline & & Adanya distribusi konsentrasi pengambilan keputusan pada suatu organisasi / desentralisasi [21], [20] \\
\hline & & Adanya sistem penghargaan sesuai dengan keterlibatannya pada proses KM [24] [20] \\
\hline \multirow[t]{3}{*}{3} & \multirow[t]{3}{*}{$\begin{array}{l}\text { Infrastruktur } \\
\mathrm{TI}\end{array}$} & $\begin{array}{l}\text { Adanya sistem berbasis TI (baik hardware maupun software) yang mendukung proses KM [18], [20], [9], } \\
{[17],[22],[23]}\end{array}$ \\
\hline & & Adanya penggunaan TI terkait proses KM [24] \\
\hline & & Adanya fasilitas atau prosedur untuk mendukung keamanan data dan informasi [23] \\
\hline \multirow[t]{2}{*}{4} & \multirow[t]{2}{*}{$\begin{array}{l}\text { Pengetahuan } \\
\text { umum }\end{array}$} & $\begin{array}{l}\text { Adanya kumpulan pengetahuan organisasi yang meliputi segala informasi spesifik bagi organisasi [9], [18], } \\
\text { [24] }\end{array}$ \\
\hline & & Adanya pemahaman tentang KM [9] \\
\hline \multirow[t]{2}{*}{5} & \multirow[t]{2}{*}{$\begin{array}{l}\text { Lingkungan } \\
\text { Fisik }\end{array}$} & $\begin{array}{l}\text { Adanya ruangan khusus bagi individu-individu dalam organisasi untuk bertemu dan berbagi pengetahuan } \\
\text { [24] }\end{array}$ \\
\hline & & $\begin{array}{l}\text { Adanya desain ruang kerja yang memudahkan untuk berinteraksi antar individu dalam rangka berbagi } \\
\text { pengetahuan [9] }\end{array}$ \\
\hline \multirow[t]{3}{*}{6} & \multirow[t]{3}{*}{ Strategi KM } & Adanya strategi untuk mendukung KM [23] \\
\hline & & Adanya keselarasan antara strategi KM dengan strategi organisasi [18], [22] \\
\hline & & Adanya evaluasi terhadap performa KM [23] \\
\hline \multirow[t]{2}{*}{7} & \multirow[t]{2}{*}{$\begin{array}{l}\text { Kepemim- } \\
\text { pinan }\end{array}$} & $\begin{array}{l}\text { Adanya dukungan dan komitmen dari pimpinan/manajemen baik dalam bentuk program kerja, arahan } \\
\text { maupun penyediaan sumber daya untuk mendukung kegiatan KM [18], [21], [22], [23], [24] }\end{array}$ \\
\hline & & Adanya anggaran untuk memfasilitasi atau mendukung kegiatan KM [23] \\
\hline \multirow[t]{3}{*}{8} & \multirow{3}{*}{$\begin{array}{l}\text { Pembelajar- } \\
\text { an }\end{array}$} & Adanya kesempatan diklat yang merata untuk meningkatkan pengetahuan [24] \\
\hline & & Adanya relevansi program diklat terkait inisiatif KM [24] \\
\hline & & $\begin{array}{l}\text { Adanya penciptaan pengetahuan baru yang bermanfaat bagi organisasi (best practice) dari hasil diklat, } \\
\text { pengalaman individu maupun benchmarking dengan organisasi lain [23], [18], [20], [31] }\end{array}$ \\
\hline \multirow[t]{3}{*}{9} & \multirow{3}{*}{$\begin{array}{l}\text { Kemampuan } \\
\text { dan keahlian }\end{array}$} & Adanya kemampuan dan keahlian individu yang dibutuhkan oleh organisasi [21], [18] \\
\hline & & Adanya pemerataan pengetahuan pada masing-masing individu [24] \\
\hline & & Adanya kemampuan untuk mempelajari atau meneliti hal baru dalam organisasi [24] \\
\hline \multirow[t]{3}{*}{10} & \multirow[t]{3}{*}{ Motivasi } & Adanya tren bagi individu untuk melakukan atau mengambil peran dalam proses KM [21], [23] \\
\hline & & Adanya kompetisi antar individu dalam melakukan proses KM [24] \\
\hline & & Adanya keyakinan bagi individu bahwa dengan melakukan proses KM akan meningkatkan kinerja [21] \\
\hline
\end{tabular}

Menurut Sugiyono [30], pengujian hipo-tesis deskriptif pada dasarnya merupakan proses pengujian generalisasi hasil penelitian yang didasarkan pada satu sampel variabel. Kesimpulan yang dihasilkan dari pengujian ini adalah apakah hipotesis yang diuji itu dapat digeneralisasikan.

Adapun teknik analisis statistik yang digunakan untuk pengujian tergantung pada bentuk hipotesis dan jenis data yang akan dianalisis. Oleh karena penelitian ini menggunakan bentuk hipotesis deskriptif dan jenis datanya interval (skala likert yang diberi bobot) maka analisis data yang digunakan adalah analisis statistik inferensial uji t.

Menurut Sugiyono [30], uji t dikenal dengan uji parsial, yaitu untuk menguji bagaimana pengaruh masing-masing variabel bebasnya secara sendiri-sendiri terhadap variabel terikatnya. Jika dikaitkan dengan konteks penelitian ini maka tujuan uji $\mathrm{t}$ adalah untuk mengetahui apakah ada perbe-

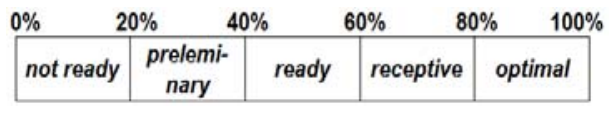

Gambar 2. Skala KM Readiness (dalam satuan \%) daan signifikan antara nilai rata-rata sampel dibandingkan dengan nilai rata-rata populasi.

Uji ini dapat dilakukan dengan membandingkan $t$ hitung dengan $t$ tabel atau dengan melihat kolom signifikansi pada masing-masing t hitung. Jenis uji t yang digunakan adalah uji t satu sampel atau parsial karena pengujiannya dilaku-kan pada satu kolom.

Nilai t tabel diketahui berdasarkan tabel $\mathrm{t} \mathrm{Su}-$ giyono [30] dengan asumsi error level 5\% (penelitian sosial) dan jenis pengujian hipotesisnya one tail test atau uji satu pihak karena hipotesisnya menggunakan operator $\geq$ atau $\leq$.

Cara pengambilan kesimpulannya adalah jika nilai t hitung lebih besar atau lebih kecil (tergantung operatornya) dari t tabel maka hipotesis nol diterima dan hipotesis alternatif ditolak, demikian juga sebaliknya.

\section{Variabel dan Indikator Penelitian}

Perancangan instrumen penelitian pada penelitian ini dilakukan dengan memetakan variabel dari KM infrastructure, KM enabler, dan KMCSF. Hal ini disebabkan karena ketiga hal ini meru-pakan 
TABEL 2

PERHITUNGAN TOTAL KM READINESS

\begin{tabular}{lll}
\hline \multicolumn{1}{c}{ Aspek } & \multicolumn{1}{c}{ Variabel } & Nilai \\
\hline Hard & Infrastruktur TI & $76,47 \%$ \\
\cline { 2 - 3 } $78,03 \%$ & Lingkungan Fisik & $79,58 \%$ \\
\hline \multirow{2}{*}{ Soft } & Budaya organisasi & $84,01 \%$ \\
\cline { 2 - 3 } $74,25 \%$ & Struktur organisasi & $65,61 \%$ \\
\cline { 2 - 3 } & Kepemimpinan & $74,57 \%$ \\
\cline { 2 - 3 } & Pembelajaran & $77,26 \%$ \\
\cline { 2 - 3 } & Kemampuan dan keahlian & $71,47 \%$ \\
\cline { 2 - 3 } & Motivasi & $72,58 \%$ \\
\hline Abstract & Pengetahuan umum & $71,42 \%$ \\
\cline { 2 - 3 } $71,57 \%$ & Strategi KM & $71,72 \%$ \\
\hline Rata-rata & & $74,47 \%$ \\
\hline
\end{tabular}

variabel penting untuk membangun sebuah KM pada organisasi.

Pemetaan dilakukan dengan mengelompokkan variabel-variabel tersebut yang memiliki kesamaan makna dan ruang lingkup. Selanjutnya dilakukan validasi oleh ahli di bidang KM atau dalam hal ini dosen KM, dan pejabat di BPPK yang mengikuti perkembangan KM BPPK dan atau menjadi tim KM BPPK, serta widyaiswara BPPK yang merupakan ujung tombak dari KM BPPK. Tabel 1 hasil dari pemetaan tersebut.

Variabel penelitian tersebut juga dipetakan ke dalam tiga aspek KM yaitu: hard (infrastruktur TI, lingkungan fisik), soft (budaya organisasi, struktur organisasi, kepemimpinan, pembelajaran, kemampuan dan keahlian, motivasi), dan abstract (pengetahuan umum, strategi KM).

\section{Penyusunan Tingkat Kesiapan KM}

Penamaan tingkatan kesiapan KM pada penelitian ini mengacu pada penelitian Rao [32] yang membagi tingkat kesiapan menjadi lima tingkatan yaitu not ready, preliminary, ready (accepted), receptive (advocating and measuring), dan optimal (institusionalized). Berdasarkan lima tingkatan tersebut kemudian Zaidiah [29] membuat skala tingkatan kesiapan KM sebagaimana ditunjukkan pada Gambar 2.

Zaidiah [29] menggunakan persentase yang proporsional pada setiap tingkatannya. Tingkat not ready artinya organisasi tersebut belum siap menerapkan KM. Tingkat preleminary artinya organisasi tersebut masih perlu dilakukan langkahlangkah untuk mencapai kesiapan KM. Tingkat ready artinya organisasi tersebut telah siap menerapkan KM. Tingkat receptive artinya organisasi tersebut sudah ada efisiensi dari proses KM dan standard/aturan KM. Tingkat optimal artinya organisasi tersebut statusnya memiliki kemampuan beradaptasi terhadap ketentuan untuk mencapai KM readiness.

\section{Penyusunan Kuesioner Penelitian}

Instrumen kuesioner disusun berdasarkan variabel dan indikator penelitian.

\section{Hasil dan Pembahasan}

\section{Uji Validitas dan Reliabilitas}

Jumlah responden yang digunakan pada uji validitas dan reliabilitas ini adalah 32 orang atau $10 \%$ dari total jumlah responden pada penelitian ini.

Berdasarkan hasil uji validitas diketahui bahwa terd apat tiga pertanyaan yang tidak valid. Oleh karenanya, strategi yang dilakukan terhadap tiga pertanyaan tersebut adalah pertanyaan tersebut tidak akan dimasukkan ke dalam perhitungan

Berdasarkan uji reliabilitas, diketahui bahwa tingkat reliabilitas semua variabel penelitian ini baik dan atau dapat diterima sehingga dapat disimpulkan bahwa instrumen penelitian dari kesepuluh variabel tersebut dapat menghasilkan data yang konsisten dari waktu ke waktu

\section{Pengumpulan Data}

Proses pengumpulan data ini dilakukan dengan menyebarkan kuesioner penelitian ke seluruh unit kerja di lingkungan BPPK. Terdapat dua versi kuesioner yang digunakan pada pen-elitian ini yaitu versi online dan offline.

Periode penyebaran kuesioner dilakukan mulai tanggal 8 November 2016 sampai dengan 4 Desember 2016. Total kuesioner yang disebar adalah sebanyak 372 kuesioner dan yang mengembalikan atau mengisi kuesioner sebanyak 309 responden.

\section{Analisis Tingkat Kesiapan KM}

Proses penilaian tingkat kesiapan penera-pan KM di BPPK ini menggunakan metode sta-tistik deskriptif rata-rata dari keseluruhan variabel KM, kemudian dibandingkan dengan tingkat kes-iapan $\mathrm{KM}$ atau KM readiness level.

Secara keseluruhan, nilai rata-rata semua variabel dalam penelitian ini adalah 74,47\%. Oleh karenanya, berdasarkan tingkat kesiapan KM maka nilai tersebut berada pada tingkat receptive karena berada pada range $61 \%$ sampai dengan $80 \%$, artinya menurut persepsi dari responden disimpulkan bahwa semua indikator pada masingmasing variabel penelitian sudah sangat mendukung untuk diterapkannya KM.

Hasil tingkat kesiapan tersebut perlu diuji terelebih dahulu sebelum digeneralisasi ke populasi yaitu apakah ada perbedaan signifikan antara nilai rata-rata keseluruhan variabel penelitian ini yang berada pada level receptive (61\% sampai 
dengan $80 \%$ ) dibandingkan dengan nilai rata-rata populasi.

Untuk mencapai receptive maka nilai ratarata minimal yang harus dicapai adalah $61 \%$. Berdasarkan hal tersebut maka rumusan hipotesisnya sebagai berikut: $H_{o}: \mu_{o} \geq 61 \%$ dan $H_{a}: \mu_{o}<61 \%$

Pengujian hipotesis ini dilakukan dengan dengan menggunakan statistik inferensial uji $\mathrm{t}$ parsial one sample. Uji $\mathrm{t}$ ini dilakukan dengan asumsi bahwa data yang dianalisis berdistribusi normal. Oleh karenanya perlu dipastikan dahulu bahwa data tersebut normal melalui uji normalitas data.

Hasil uji normalitas Kolmogorov-Smirnov menunjukkan nilai perhitungan signifikansinya (Asymp. Sig) sebesar 0,293 atau lebih besar dari nilai signifikansi yang ditentukan yaitu 0,05 . Sehingga data diasumsikan normal.

\section{Uji T}

Uji t dilakukan untuk menguji hipotesis berikut. $H_{o}: \mu_{o} \geq 61 \%$ dan $H_{a}: \mu_{o}<61 \%$. Di-ketahui jumlah sampel sebanyak 309 , error level 5\%, sehingga nilai t tabel adalah 1,645.

$$
\begin{gathered}
t=\frac{\bar{X}-\mu_{0}}{s / \sqrt{n}} \\
178.916-146.4 /(24,8 / \sqrt{ } 309)=23,05
\end{gathered}
$$

Berdasarkan perhitungan di atas diketahui bahwa nilai thitung $(23,05)$ lebih besar dari t tabel $(1,645)$, sehingga hipotesis nol yang menyatakan nilai rata-rata lebih besar sama dengan $61 \%$ diterima dan hipotesis nol ditolak.

Oleh karena itu dapat disimpulkan bahwa posisi BPPK menurut persepsi dari pegawainya berada pada level receptive (61-80\%) artinya semua indikator dalam KM sudah sangat mendukung untuk diterapkannya KM di BPPK.

\section{Implikasi Penelitian}

Secara umum dapat disimpulkan bahwa BPPK sudah siap dalam menerapkan KM. Hanya saja ada satu variabel yang nilainya jauh di bawah rata-rata $(74,61 \%)$ yaitu variabel struktur organisasi $(65,61 \%)$. Oleh karenanya berdasarkan indikator pada variabel tersebut maka penulis memberikan beberapa rekomendasi yang memang belum dilakukan oleh BPPK.

1) Membentuk unit khusus yang bertanggung jawab terhadap proses KM di BPPK

2) Menunjuk SDM yang bertugas sebagai Chief Knowledge Officer.
3) Memberikan peran yang lebih kepada para pegawai untuk turut terlibat dalam pengambilan keputusan organisasi dengan meningkatkan intensitas diskusi ilmiah.

4) Memberikan aturan terkait reward atau penghargaan terhadap pegawai atas keterlibatannya dalam proses atau kegiatan KM.

Jika ditinjau dari aspek KM maka aspek $a b$ stract ini mendapatkan nilai paling rendah yaitu $71,57 \%$. Berdasarkan indikator dari setiap variabel pada aspek abstract maka penulis memberikan beberapa rekomendasi yaitu dengan lebih menggalakkan lagi kegiatan-kegiatan yang bertujuan untuk mensosialiasikan KM kepada seluruh pegawai, tidak hanya untuk pegawai yang menjadi tim KM saja namun juga pegawai lainnya baik di pusat maupun daerah.

\section{Kesimpulan}

Penelitian ini telah berhasil menyusun ke-rangka kerja untuk mengukur kesiapan BPPK dalam menerapkan KM yang terdiri dari sepuluh variabel penelitian (struktur organisasi, budaya organisasi, kepemimpinan, strategi $\mathrm{KM}$, pembelajaran, pengetahuan umum, kemampuan dan keahlian, motivasi, teknologi informasi, dan lingkungan fisik) dan diklasifikasikan ke dalam tiga aspek KM ( $a b-$ stract, hard, dan soft) serta penilaiannya menggunakan 5 tingkat kesiapan KM (not ready, preleminary, ready, receptive, dan optimal).

Tingkat kesiapan penerapan KM BPPK berada pada tingkat receptive yang mengindi-kasikan bahwa semua indikator dalam KM sudah sangat mendukung untuk diterapkannya KM di BPPK.

Diharapkan BPPK bisa segera menerapkan KM karena tingkat kesiapan penerapan KM-nya telah berada pada tingkat receptive serta menerapkan rekomendasi yang diajukan oleh penulis guna meningkatkan tingkat kesiapan tersebut.

Pada penelitian ini penentuan sampelnya menggunakan teknik convenience sampling (non probability sampling). Oleh karena itu, pada penelitian selanjutnya sebaiknya menggunakan teknik probablity sampling sehingga diharapkan sampel yang didapat lebih mendekati representasi dari populasi.

Pada penelitian ini, aspek dan variabel penelitian yang memengaruhi kesiapan KM diasumsikan memiliki bobot yang sama. Sehingga tidak dapat diketahui dengan pasti tingkat kontribusi masing-masing aspek atau variabel tersebut terhadap kesiapan KM. Oleh karena itu pada peneli-tian selanjutnya sebaiknya terlebih dahulu dilaku-kan pengukuran terhadap bobot masing-masing aspek atau variabel sebelum digunakan untuk pengukuran kesiapan KM. 


\section{Referensi}

[1] Kementerian Keuangan, Peraturan menteri keuangan 184 tahun 2010 tentang organisasi dan tata kerja Kemenkeu, Jakarta: Kementerian Keuangan, 2010.

[2] Pemerintah Republik Indonesia, Peraturan presiden no. 81 tahun 2010 tentang grand design reformasi birokrasi 2010-2025, Jakarta: Republik Indonesia, 2010.

[3] Kementerian Keuangan, Keputusan menteri keuangan no. 36 tahun 2014 tentang cetak biru program transformasi kelembagaan Kemenkeu 2014-2025, Jakarta: Kementerian Keuangan, 2014.

[4] M. Allen, The corporate university handbook, New York: Amacom, 2002.

[5] M. Allen, The next generation of corporate universities, San Francisco: Pfeiffer, 2007.

[6] Kementerian Keuangan, Keputusan menteri keuangan no. 466 tahun 2015 tentang rencana strategis Kemenkeu 2015-2019, Jakarta: Kementerian Keuangan, 2015.

[7] J. A. Mulyono, H. Harisno dan C. N. Kristianto, "The development of knowledge management system model in xyz corporation," dalam Teaching, Assessment and Learning for Engineering (TALE), Bali, 2013.

[8] L. H. Atrinawati dan K. Surendro, "Assessment for knowledge management readiness," International Conference on Electrical Engineering and Informatics, 2009.

I. B. Fernandez dan R. Sabherwal, Knowledge management, New York: Routledge, 2015.

[9] L. Crane, Knowledge and discourse matters: Relocating knowledge management's sphere of interest onto language, New Jersey: John Wiley dan Sons, Inc, 2016.

[10] E. C. Cheng, Knowledge management for school education, London: Springer, 2015.

[11] D. T. Holt, S. E. Bartczak, S. W. Clark dan M. R. Trent, "The development of an instrument to measure readiness for knowledge management.," dalam 37th Annual Hawaii International Conference on System Sciences, Hawaii, 2004.

[12] N. S. A. Karim, M. J. M. Razi dan N. Mohamed, "Measuring employee readiness for knowledge management using intention to be involved with KM SECI processes," Business Process Management Journal , pp. 777-791, 2012.

[13] K. Mohammadi, A. Khanlari dan B. Sohrabi, "Organizational readiness assessment for knowledge management," International Journal of Knowledge Management Vol 5 Issue 1, pp. 29-45, 2009.
[14] H. dan. C. B. Lee, "Knowledge management enablers, processes, and organizational performance: An integration and empirical examination," Journal of Management Information Systems, p. 179-228, 2003.

A. W. Fitriadi, Analisis tingkat kesiapan implementasi knowledge management (KM readiness): Studi kasus badan pusat statistik republik indonesia, Universitas Indonesia, 2016.

[15] F. Setiawan, Analisa pengukuran tingkat kesiapan implementasi knowledge management (KM readiness) pada PT fajar hutama mandiri, Universitas Indonesia, 2013.

[16] K. Al-Mabrouk, "Critical success factors affecting knowledge management adoption: A review of the literature," Innovations in Information Technology, pp. 1-6, 2006.

[17] S. Nejadhussein dan P. Azadbakht, "Knowledge management readiness in a university in iran," Journal of Knowledge-based Innovation in China, pp. Vol. 3 Iss 3 pp. 172 - 183, 2011.

[18] S. I. Pradana, A. Kurniawati dan N. Ambarsari, "Knowledge management system implementation readiness measurement in PDII LIPI based on people and organizational structure factors," Procedia Manufacturing 4, p. $216-223,2015$.

[19] R. Rafieyzadeh, S. A. Ahmadi dan D. Vahdat, "Assessing organizational readiness for knowledge management system implementation (case study: Department of information technology development at the ministry of industry, mine and trade)," A Journal of Economics and Management Vol. 3 Issue 4 April 2014, pp. 109-123, 2014.

[20] N. D. Mamaghani, R. Samizadeh dan F. Saghafi, "Evaluating the readiness of iranian research centers in knowledge management," American Journal of Economics and Business Administration Volume 3, Issue 1, pp. 203-212, 2011.

[21] Y. Al-Bastaki dan A. Shajera, "Organisational readiness for knowledge management: University of bahrain case study," European Conference on Knowledge Management, p. 10, 2012.

[22] R. R. H. dan. H.-F. M. H. Mahmod, "Knowledge management and innovation readiness among SME's in malaysia," IEEE Business Engineering and Industrial Applications Colloquium (BEIAC), p. 698-702, 2013.

[23] V. Hlupic, A. Pouloudi dan G. Rzevski, "Towards an integrated approach to knowledge management: "hard", "soft", and "abstract" issues," Knowledge and Process Management 9(2), p. 90-102, 2002. 
[24] J. W. Creswell, Research design: Qualitative, quantitative, and mixed methods approaches, California: Sage, 2011.

[25] Sugiyono, Metodologi penelitian pendidikan pendekatan kualitatif, kuantitatif dan RdanD, Bandung: Alfabeta, 2016.

[26] A. Zaidiah, Analisis pengukuran tingkat kesiapan implementasi knowledge management (KM readiness) pada sekretariat badan pendidikan dan pelatihan kementerian pertahanan, Universitas Indonesia, 2011.

[27] Sugiyono, Statistika untuk penelitian, Bandung: Alfabeta, 2016.

[28] F. A. Kuddah, Analisa pengukuran tingkat kesiapan implementasi knowledge manage- ment (KM readiness): Studi kasus pada direktorat informasi kepabeanan dan cukai direktorat jenderal bea cukai (DJBC), Universitas Indonesia, 2014.

[29] M. Rao, Knowledge management tools and techniques: Practitioners and experts evaluate KM solutions, Burlington: Elsevier Butterworth-Heinemann, 2005.

[30] B. Bergeron, Essentials of knowledge management, New Jersey: John WileydanSons Inc, 2003.

[31] U. Sekaran dan R. Bougie, Research methods for business, Chichester: John Wiley dan Sons, 2013. 